\title{
Development of a novel tool for automation of the contamination measurement
}

\author{
Alena Wernke and Sascha Gentes \\ Karlsruhe Institute of Technology (KIT) - Institute for Technology and Management in Construction (TMB), \\ 76131 Karlsruhe, Germany \\ Correspondence: Alena Wernke (alena.wernke@kit.edu) \\ Published: 10 November 2021
}

\begin{abstract}
Considering that about $100000 \mathrm{~m}^{2}$ of wall area per nuclear facility must be decontaminated (Hübner et al., 2017), the automation of mechanical decontamination work offers high potential to support people in performing their work and reduce errors in the decommissioning process. Furthermore, the exposure potential for people in contaminated environments is reduced and they are protected from health hazards (Petereit et al., 2019).

In the ROBDEKON project, a competence center is being established in Germany to develop practical robotic systems for decontamination work in hazardous environments. To this end, four research institutions are working with industrial partners on the development of (partially) autonomous robotic systems for the decommissioning and decontamination of nuclear facilities, the handling of waste, and the remediation of landfills and contaminated sites (Petereit et al., 2019).

At the Institute for Technology and Management in Construction (KIT-TMB), the focus is on development of an automated solution for the (clearance) measurement of near-surface contaminations. A mobile elevating working platform is used as the robotic platform with a contamination array as the tool. The array measures the surface activity on the wall areas and verifies compliance with the thresholds. The contamination array is based on two sensor concepts: measurement and localization. Up to four hand-held contamination-measuring devices are attached to the array to parallelize the measurement. In order to avoid damaging the sensitive detector window foil of the contamination probes, the wall surface to be measured is first examined for imperfections with the help of a laser scanner. For localization of the array, up to four laser sensors are used for distance measurements. Measurement results are automatically saved after each measurement in a table specific to the measurement method and are available to users for documentation purposes at any time. In the further course of the project, the measurement results depending on the radiation level will be overlaid with a geometric 3D environment mapping.
\end{abstract}

Kurzfassung. In Anbetracht der Tatsache, dass pro kerntechnischer Anlage etwa $100.000 \mathrm{~m}^{2}$ Wandfläche dekontaminiert werden müssen (Hübner et al., 2017), bietet die Automatisierung maschineller Dekontaminationsarbeiten ein hohes Potenzial, das Personal bei der Durchführung dieser Arbeiten zu unterstützten und Fehler im Stilllegungsprozess zu reduzieren. Darüber hinaus wird das Expositionspotenzial für Menschen in kontaminierten Umgebungen verringert, und sie werden vor Gesundheitsgefahren geschützt (Petereit et al., 2019).

Im Rahmen des Projekts ROBDEKON wird in Deutschland ein Kompetenzzentrum aufgebaut, das praxisnahe Robotersysteme für Dekontaminationsarbeiten in gefährlichen Umgebungen entwickelt. Dazu arbeiten vier Forschungseinrichtungen mit Industriepartnern an der Entwicklung (teil-)autonomer Robotersysteme für die Stilllegung und Dekontamination kerntechnischer Anlagen, die Handhabung von Abfällen sowie die Sanierung von Deponien und Altlasten (Petereit et al., 2019).

Am Institut für Technologie und Management im Baubetrieb des Karlsruher Instituts für Technologie (KITTMB) liegt der Schwerpunkt auf der Entwicklung einer automatisierten Lösung für das (Frei-) Messen oberflächennaher Kontaminationen. Dabei wird eine mobile Hubarbeitsbühne als Roboterplattform mit einem Kontaminationsarray als Werkzeug eingesetzt. Das Array misst die Oberflächenaktivität auf den Wandflächen und 
überprüft die Einhaltung der Grenzwerte. Das Kontaminationsarray basiert auf zwei Sensorkonzepten: Messung und Lokalisierung. Zur Parallelisierung der Messung werden bis zu vier tragbare Kontaminationsmessgeräte an das Array angebracht. Um die empfindliche Detektorfensterfolie der Kontaminationssonden nicht zu beschädigen, wird die zu messende Wandoberfläche zunächst mit Hilfe eines Laserscanners auf Unebenheiten untersucht. Zur Lokalisierung des Arrays werden bis zu vier Lasersensoren für Abstandsmessungen eingesetzt. Die Messergebnisse werden nach jeder Messung automatisch in einer messverfahrensspezifischen Tabelle gespeichert und stehen den Anwendern jederzeit zu Dokumentationszwecken zur Verfügung. Im weiteren Verlauf des Projekts werden die radiologischen Messergebnisse je nach Strahlungsniveau in einer 3DUmgebungskartierung dargestellt.

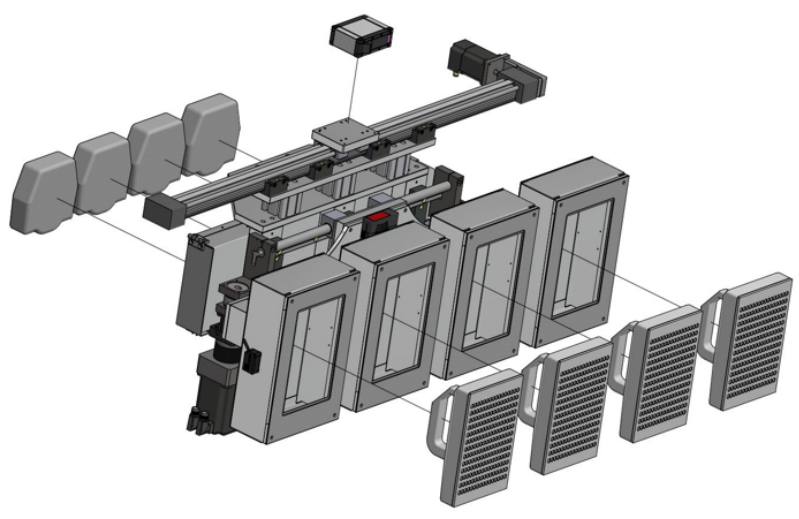

Figure 1. Schematic concept of the contamination array.

\section{References}

Hübner F., von Grone, G., und Schultmann, F.: Technologien zur Zerlegung und zur Dekontamination von kerntechnischen Anlagen, 2017, Institut für Industriebetriebslehre und Industrielle Produktion (IIP), Karlsruher Institut für Technologie 30 (KIT), Karlsruhe, https://doi.org/10.5445/IR/1000067419, 2017.
Petereit, J., Beyerer, J., Asfour, T., Gentes, S., Hein, B., Hanebeck, U. D., Kirchner, F., Dillmann, R., Götting, H. H., Weiser, M., Gustmann, M., and Egloffstein, T.: ROBDEKON: Robotic Systems for Decontamination in Hazardous Environments, in: 2019 IEEE International Symposium on Safety, Security, and Rescue Robotics (SSRR), Würzburg, 249-255, 2019. 